\title{
Chaetolines A and B, Pyrano[3,2-f]isoquinoline Alkaloids from Cultivation of Chaetomium sp. in the Presence of Autoclaved Pseudomonas aeruginosa
}

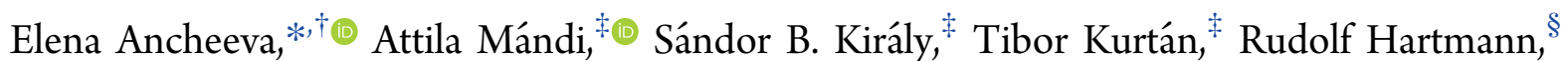

Sergi H. Akone, ${ }^{\dagger, \perp}$ Horst Weber, $\|$ Georgios Daletos, ${ }^{*},{ }^{\dagger}$ and Peter Proksch ${ }^{*}{ }^{\dagger}$

${ }^{\dagger}$ Institute of Pharmaceutical Biology and Biotechnology, Heinrich Heine University, Universitätsstrasse 1, 40225 Düsseldorf, Germany

${ }^{\ddagger}$ Department of Organic Chemistry, University of Debrecen, PO Box 400, 4002 Debrecen, Hungary

${ }^{\S}$ Institute of Complex Systems: Strukturbiochemie (ICS-6), Forschungszentrum Jülich, Wilhelm-Johnen-Strasse, 52428 Jülich, Germany

${ }^{\perp}$ Faculty of Science, Department of Chemistry, University of Douala, PO Box 24157, Douala, Cameroon

"Institute of Pharmaceutical and Medicinal Chemistry, Heinrich Heine University, Universitätsstrasse 1, 40225 Düsseldorf, Germany

Supporting Information

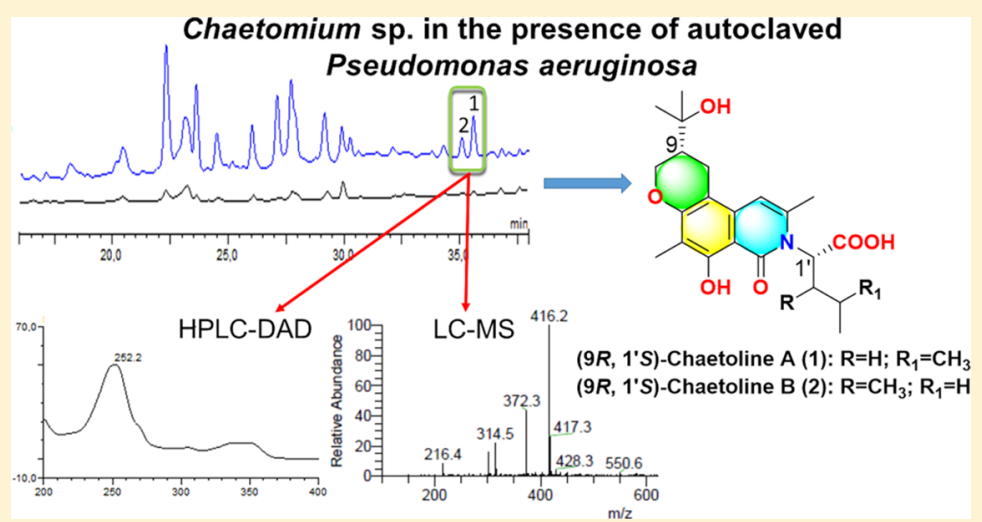

ABSTRACT: The first members of a new alkaloid class, chaetolines A (1) and B (2), which feature a pyrano[3,2$f$ ]isoquinoline core structure, were obtained from a crude extract of the fungal endophyte Chaetomium sp. after cultivation in the presence of autoclaved Pseudomonas aeruginosa. The structures of the new compounds, including the absolute configuration of the major stereoisomer, were determined through detailed analysis of HRESIMS, 1D/2D NMR, and calculation of ECD data. The possible biosynthetic origin of the unprecedented scaffold of $\mathbf{1}$ and $\mathbf{2}$ is proposed. The current study provides further evidence for mixed fermentation as a powerful tool to induce the accumulation of cryptic fungal natural products even in the absence of viable bacterial cells.

$G$ enome sequence analyses of numerous filamentous fungi

revealed that their biosynthetic capacity is only partially expressed under standard laboratory conditions. ${ }^{1}$ Activation of silent genes employing variations of growth conditions, epigenetic modification, or genetic engineering has become a powerful tool for accelerating the discovery of new secondary metabolites. Recent studies on the epigenetic manipulation of Chaetomium mollipilium and Chaetomium indicum using histone deacetylase (HDAC) inhibitors, such as nicotinamide or suberoyl bis-hydroxamic acid (SBHA), significantly changed the polyketide profile of these fungi, leading to the discovery of unusual $\mathrm{C}_{13}$-polyketides, mollipilins $\mathrm{A}-\mathrm{E}$, prenylated aromatic polyketides, chaetophenols $\mathrm{A}-\mathrm{F}$, and the spirolactones, spiroindicumides $\mathrm{A}$ and $\mathrm{B}{ }^{2}$
An alternative experimental approach for the enhancement/ induction of secondary metabolism is cocultivation of different microorganisms based on the concept of an interspecies crosstalk resulting in the stimulation of silent biosynthetic gene clusters. ${ }^{1 \mathrm{~b}}$ In our previous attempts to influence the biosynthesis of secondary metabolites of the fungal endophyte Chaetomium sp. isolated from the Cameroonian plant Sapium ellipticum, we applied a cofermentation strategy using several Gram-positive and Gram-negative bacteria. ${ }^{3}$ Cultivation of Chaetomium sp. with viable Bacillus subtilis or in the presence of autoclaved Pseudomonas aeruginosa resulted in the induction

Received: May 10, 2018

Published: October 21, 2018 
of chemically distinct compounds. ${ }^{3}$ Major secondary metabolites derived from the extract of Chaetomium sp. cultivated together with autoclaved $P$. aeruginosa were identified in our earlier report as schikimic acid pathway related compounds, among them new natural products chaetoisochorismin and chaetobutenolides A-C. ${ }^{3 \mathrm{~b}}$ A detailed HPLC-DAD and LC-MS based investigation of this crude extract revealed further novel nitrogen-containing metabolites, the biosynthesis of which was induced as a result of this experiment (Figure S1). Herein, we report the structure elucidation of these alkaloids, chaetolines A (1) and B (2), bearing a novel scaffold and discuss a possible biosynthetic origin of these compounds.

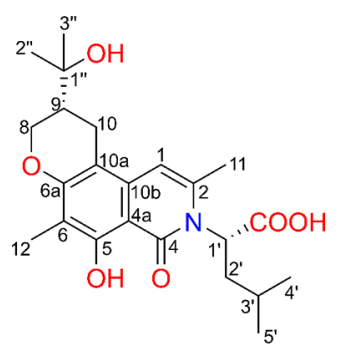

(9R,1'S)-Chaetoline A (1)

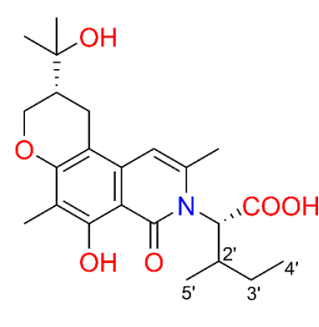

(9R,1'S)-Chaetoline B (2)

\section{RESULTS AND DISCUSSION}

Chaetoline A (1) was isolated as an amorphous, yellowish powder. Its molecular formula, $\mathrm{C}_{23} \mathrm{H}_{31} \mathrm{NO}_{6}$, exhibiting 9 degrees of unsaturation, was deduced from the HRESIMS data. The ${ }^{1} \mathrm{H}$ NMR spectrum of 1 recorded in DMSO- $d_{6}$ displayed signals of one aromatic proton ( $\mathrm{H}-1)$, three sets of methylene signals $\left(\mathrm{H}_{2}-8, \mathrm{H}_{2}-10, \mathrm{H}_{2}-2^{\prime}\right)$, three methine protons ( $\left.\mathrm{H}-9, \mathrm{H}-1^{\prime}, \mathrm{H}-3^{\prime}\right)$, and six methyl signals $\left(\mathrm{H}_{3}-2^{\prime \prime}, \mathrm{H}_{3}-3^{\prime \prime}, \mathrm{H}_{3}-11\right.$, $\mathrm{H}_{3}-12, \mathrm{H}_{3}-4^{\prime}, \mathrm{H}_{3}-5^{\prime}$ ) (for detailed NMR signal characterization see Table 1). Analysis of ${ }^{13} \mathrm{C}, \mathrm{HMBC}$, and HSQC NMR spectra allowed the assignment of the respective carbons. Interpretation of the COSY spectrum of $\mathbf{1}$ indicated the presence of a spin system starting from the oxygenated methylene $\mathrm{H}_{2}-8$ and extending to the methylene group $\mathrm{H}_{2}-10$. The HMBC spectrum confirmed the established substructure and revealed further correlations from $\mathrm{H}_{2}-10$ to C-6a and C-8 and from $\mathrm{H}_{2}-8$ to $\mathrm{C}-10$ and $\mathrm{C}-6 \mathrm{a}$, thus suggesting the presence of a pyran. Moreover, a hydroxyisopropyl was attached to C-9, as supported by the HMBC correlations from the methyl groups $\mathrm{H}_{3}-2^{\prime \prime}$ and $\mathrm{H}_{3}-3^{\prime \prime}$ to $\mathrm{C}-1^{\prime \prime}$ and $\mathrm{C}-9$ as well as from $1^{\prime \prime}$ $\mathrm{OH}$ to C-9 (unit I; Figure 1). Additional HMBC correlations from $\mathrm{H}_{2}-10$ to $\mathrm{C}-10 \mathrm{a}$ and $\mathrm{C}-10 \mathrm{~b}$, and from the methyl group $\mathrm{H}_{3}-12$ to C-6a, C-6, and C-5 indicated that unit I was fused to a substituted benzene ring at C-6a and C-10a. Moreover, a propenyl group $\mathrm{C}-1 / \mathrm{C}-2 / \mathrm{C}-11$ was located at $\mathrm{C}-10 \mathrm{~b}$ of the

Table 1. ${ }^{1} \mathrm{H}$ and ${ }^{13} \mathrm{C}$ NMR Data of 1 Recorded in DMSO- $d_{6}$

\begin{tabular}{|c|c|c|c|c|}
\hline position & $\delta_{\mathrm{C}}$, type $^{a}$ & $\begin{array}{c}\delta_{\mathrm{H},} \text { mult. } \\
(J \text { in } \mathrm{Hz})^{a}\end{array}$ & $\delta_{\mathrm{C},}$ type $^{b, c}$ & $\begin{array}{l}\delta_{\mathrm{H}}, \text { mult. } \\
(J \text { in } \mathrm{Hz})^{b}\end{array}$ \\
\hline 1 & 103.6, CH & $6.62 \mathrm{~s}$ & 103.5, $\mathrm{CH}$ & $6.62 \mathrm{~s}$ \\
\hline 2 & 139.3, C & & $139.3, \mathrm{C}$ & \\
\hline 4 & 165.3, C & & 165.2, C & \\
\hline $4 a$ & 104.3, C & & 104.3, C & \\
\hline 5 & 156.8, C & & 156.7, C & \\
\hline 6 & 108.1, C & & 108.1, C & \\
\hline $6 a$ & 157.5, C & & $157.4, \mathrm{C}$ & \\
\hline 8 ax. & 67.7, $\mathrm{CH}_{2}$ & $\begin{array}{l}3.77 \mathrm{t}(10.9) / \\
3.75 \mathrm{t}(10.9)^{d}\end{array}$ & 67.6, $\mathrm{CH}_{2}$ & $\begin{array}{l}3.74 \mathrm{t}(10.8) / \\
3.73 \mathrm{t}(10.8)^{d}\end{array}$ \\
\hline 8 eq. & & 4.54 br d (10.9) & & $4.53 \mathrm{br} \mathrm{d}(10.8)$ \\
\hline 9 & $42.33 / 42.25,{ }^{d} \mathrm{CH}$ & $1.87^{e}$ & $42.2, \mathrm{CH}$ & $1.87^{e}$ \\
\hline 10 ax. & 22.7, $\mathrm{CH}_{2}$ & $2.51,^{e}$ & 22.7, $\mathrm{CH}_{2}$ & $\begin{array}{l}2.52 \mathrm{br} \mathrm{t}(16.0) / \\
2.51^{d, e}\end{array}$ \\
\hline 10 eq. & & $2.77 \mathrm{~m}$ & & $\begin{array}{l}2.75 \mathrm{br} \mathrm{dd}(16.0,5.3) / \\
2.76 \mathrm{br} \mathrm{dd}(16.0,5.3)^{d}\end{array}$ \\
\hline $10 \mathrm{a}$ & 104.7, C & & 104.7, C & \\
\hline $10 \mathrm{~b}$ & $134.4, \mathrm{C}$ & & 134.4, C & \\
\hline 11 & $20.8, \mathrm{CH}_{3}$ & $2.44 \mathrm{~s}$ & $20.8, \mathrm{CH}_{3}$ & $2.44 \mathrm{~s}$ \\
\hline 12 & $8.0, \mathrm{CH}_{3}$ & $2.00 \mathrm{~s}$ & 8.0, $\mathrm{CH}_{3}$ & $1.98 \mathrm{~s}$ \\
\hline $1^{\prime}$ & $57.2, \mathrm{CH}$ & 4.84 br s & 57.1, CH & $4.85 \mathrm{br} \mathrm{s}$ \\
\hline $2^{\prime}$ & 37.5, $\mathrm{CH}_{2}$ & $2.18 \mathrm{~m}, 1.89^{e}$ & 37.3, $\mathrm{CH}_{2}$ & $2.14 \mathrm{~m}, 1.90^{e}$ \\
\hline $3^{\prime}$ & $25.2, \mathrm{CH}$ & $1.52 \mathrm{~m}$ & 25.1, $\mathrm{CH}$ & $1.51 \mathrm{~m}$ \\
\hline $4^{\prime}$ & 22.9, $\mathrm{CH}_{3}$ & $0.92 \mathrm{~d}(6.7)$ & 22.9, $\mathrm{CH}_{3}$ & $0.90 \mathrm{~d}(6.6)$ \\
\hline $5^{\prime}$ & 22.7, $\mathrm{CH}_{3}$ & 0.80 br d (6.7) & 22.6, $\mathrm{CH}_{3}$ & 0.77 br d (6.6) \\
\hline $1^{\prime}-\mathrm{COOH}$ & n.o.$^{f}$ & & 171.1, C & \\
\hline $1^{\prime \prime}$ & $69.4, \mathrm{C}$ & & $69.4, \mathrm{C}$ & \\
\hline $2^{\prime \prime}$ & $27.88 / 27.83,{ }^{d} \mathrm{CH}_{3}$ & $1.21 \mathrm{~s}$ & $27.8, \mathrm{CH}_{3}$ & $1.20 \mathrm{~s}$ \\
\hline $3^{\prime \prime}$ & $26.5, \mathrm{CH}_{3}$ & $1.17 \mathrm{~s}$ & 26.4, $\mathrm{CH}_{3}$ & $1.16 \mathrm{~s}$ \\
\hline
\end{tabular}

${ }^{a}$ Measured at $T=298 \mathrm{~K} .{ }^{1} \mathrm{H}: 600 \mathrm{MHz} ;{ }^{13} \mathrm{C}: 150 \mathrm{MHz} .{ }^{b}$ Measured under acidic conditions (addition of $1.8 \% \mathrm{HCl} ; \mathrm{pH}=4 ; 6 \mu \mathrm{L} \mathrm{H}_{2} \mathrm{O}$ ) and at $T=$ $291 \mathrm{~K} .{ }^{1} \mathrm{H}$ : $750 \mathrm{MHz} ;{ }^{13} \mathrm{C}$ : $189 \mathrm{MHz} .{ }^{c}$ Chemical shifts were extracted from HSQC and HMBC spectra. ${ }^{d}$ Duplicated NMR signals due to the presence of diastereomers. ${ }^{e}$ Overlapped signals. ${ }^{f}$ Not observed. 


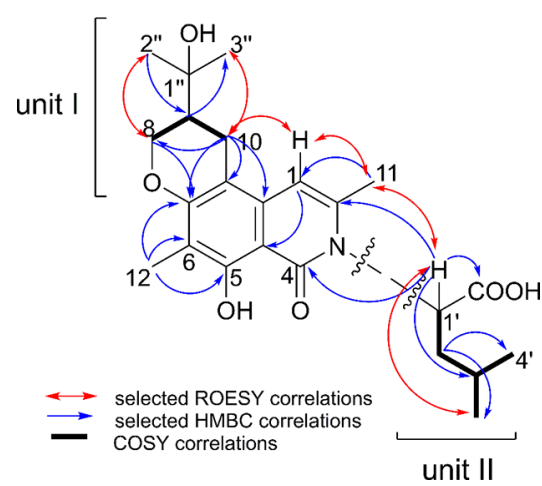

Figure 1. Key HMBC, ROESY, and COSY correlations of $\mathbf{1 .}$

aforementioned moiety, based on the HMBC correlations from $\mathrm{H}-1$ to $\mathrm{C}-10 \mathrm{a}$ and $\mathrm{C}-4 \mathrm{a}$ and from $\mathrm{H}_{3}-11$ to $\mathrm{C}-2$ and $\mathrm{C}-1$. The latter correlation was only observed when the HMBC spectrum was recorded in $\mathrm{CDCl}_{3}$ due to signal broadness of the respective group in DMSO- $d_{6}$. The remaining ${ }^{1} \mathrm{H}$ NMR resonances $\left(\mathrm{H}-1^{\prime}-\mathrm{H}_{3}-5^{\prime}\right.$; Table 1$)$, forming the continuous spin system $\mathrm{H}-1^{\prime}-\mathrm{H}_{2}-2^{\prime}-\mathrm{H}-3^{\prime}-\mathrm{H}_{3}-4^{\prime}\left(\mathrm{H}_{3}-5^{\prime}\right)$ in the COSY spectrum of 1 , hinted at the presence of a leucine residue (unit II; Figure 1). At this point, it should be noted that the absence of HMBC correlations from the broad $\alpha$-proton signal H-1' hindered the connection of this unit to the rest of the structure of 1 . To overcome this problem, additional NMR measurements were carried out at different temperatures and $\mathrm{pH}$ conditions. Accordingly, the HMBC spectrum under slightly reduced temperature $(291 \mathrm{~K})$ and acidic conditions $(\mathrm{HCl} ; \mathrm{pH}$ $=4$ ) exhibited key correlations from $\mathrm{H}-1^{\prime}$ to $\mathrm{C}-2, \mathrm{C}-2^{\prime}, \mathrm{C}-4$, and $1^{\prime}-\mathrm{COOH}$, hence forming an isoquinolinone core structure via the connection of the leucine amino group with C-2 and C-4, fulfilling the last degree of unsaturation. This was further corroborated by the characteristic chemical shifts of C$2\left(\delta_{\mathrm{C}} 139.3\right)$ and C-4 $\left(\delta_{\mathrm{C}} 165.3\right)$, as well as by the HRESIMS/ MS spectrum, which displayed prominent ion peaks at $\mathrm{m} / \mathrm{z}$ $372.2166\left[\mathrm{C}_{22} \mathrm{H}_{30} \mathrm{NO}_{4}\right]^{+}$and $303.1460\left[\mathrm{C}_{17} \mathrm{H}_{21} \mathrm{NO}_{4}\right]^{+}$, indicating subsequent elimination of a free carboxyl group and of the leucine side chain, respectively (Figure S3). Thus, the planar structure of chaetoline A (1) was established as shown.

Chaetoline B (2) was isolated as an amorphous, yellowish powder. Compound 2 displayed the same molecular formula as 1. Comparison of the $1 \mathrm{D}$ and $2 \mathrm{D}$ NMR data of 1 and 2 confirmed their close structural similarity with regard to the heterocyclic core structure but indicated a different amino acid side chain. Accordingly, the COSY spectrum of $\mathbf{2}$ revealed a continuous spin system $\mathrm{H}-\mathrm{1}^{\prime}-\mathrm{H}-2^{\prime}\left(\mathrm{H}_{3}-5^{\prime}\right)-\mathrm{H}_{2}-3^{\prime}-\mathrm{H}_{3}-4^{\prime}$, and the observed $\mathrm{HMBC}$ correlations from $\mathrm{H}-1^{\prime}$ to $\mathrm{C}-5^{\prime}, \mathrm{C}-2^{\prime}$, and $\mathrm{C}-3^{\prime}$ and from $\mathrm{H}_{3}-4^{\prime}$ to $\mathrm{C}-3^{\prime}$ and $\mathrm{C}-2^{\prime}$ argued for the presence of isoleucine instead of a leucine residue in $\mathbf{2}$ (Table 2).

The ECD spectra of $\mathbf{1}$ and $\mathbf{2}$ recorded in $\mathrm{MeOH}$ afforded distinct but weak ECD curves, suggesting an excess of one or more stereoisomers. In order to study the stereoisomeric mixture, chiral HPLC analysis of $\mathbf{1}$ and $\mathbf{2}$ was carried out using Chiralpak IA, IB, and IC stationary phases and different eluent combinations (hexane-2-propanol, hexane-EtOH, hexane$\mathrm{CH}_{2} \mathrm{Cl}_{2}$, hexane-acetonitrile, hexane-tetrahydrofuran with $0.1 \%$ trifluoroacetic acid (TFA)). Two peaks with weak optical activity were observed in the HPLC-UV and -ECD (electronic circular dichroism) chromatograms of $\mathbf{1}$ using a Chiralpak IA column and hexane-2-propanol, 9:1 (0.1\% TFA), eluent (Figure S25), the second-eluting peak of which showed a very
Table 2. ${ }^{1} \mathrm{H}$ and ${ }^{13} \mathrm{C}$ NMR Data of 2 Recorded in DMSO- $d_{6}$

\begin{tabular}{|c|c|c|}
\hline position & $\delta_{\mathrm{C}}$, type $^{a, b}$ & $\delta_{\mathrm{H}}$, mult. $(J \text { in } \mathrm{Hz})^{a}$ \\
\hline 1 & 103.5, CH & $6.62 \mathrm{~s}$ \\
\hline 2 & $139.7, \mathrm{C}$ & \\
\hline 4 & $165.3, \mathrm{C}$ & \\
\hline $4 a$ & 103.9, C & \\
\hline 5 & $156.8, \mathrm{C}$ & \\
\hline 6 & 108.2, C & \\
\hline $6 a$ & 157.6, C & \\
\hline 8 ax. & 67.7, $\mathrm{CH}_{2}$ & $3.75^{d}$ \\
\hline 8 eq. & & $4.52 \mathrm{br} d \mathrm{~d}(10.5,2.2)$ \\
\hline 9 & 42.3, $\mathrm{CH}$ & $1.87 \mathrm{~m}$ \\
\hline 10 ax. & $22.8, \mathrm{CH}_{2}$ & $2.50^{d}$ \\
\hline 10 eq. & & $2.77 \mathrm{~m}^{c}$ \\
\hline 10a & 105.0, C & \\
\hline $10 \mathrm{~b}$ & 134.6, C & \\
\hline 11 & 21.3, $\mathrm{CH}_{3}$ & $2.41 \mathrm{br} \mathrm{s}$ \\
\hline 12 & $8.1, \mathrm{CH}_{3}$ & $1.98 \mathrm{~s}$ \\
\hline $1^{\prime}$ & 63.0, $\mathrm{CH}$ & $4.39 \mathrm{~d}(9.2)$ \\
\hline $2^{\prime}$ & $32.8, \mathrm{CH}_{2}$ & $2.52^{d}$ \\
\hline $3^{\prime}$ & 24.6, $\mathrm{CH}_{2}$ & $0.81 \mathrm{~m}$ \\
\hline $4^{\prime}$ & $11.5, \mathrm{CH}_{3}$ & 0.72 br t $(7.3)$ \\
\hline $5^{\prime}$ & $18.2, \mathrm{CH}_{3}$ & 1.13 br d (6.4) \\
\hline $1^{\prime}-\mathrm{COOH}$ & $170.8, \mathrm{C}$ & \\
\hline $1^{\prime \prime}$ & 69.6, C & \\
\hline $2^{\prime \prime}$ & 27.9, $\mathrm{CH}_{3}$ & $1.19 \mathrm{~s} / 1.20 \mathrm{~s}^{c}$ \\
\hline $3^{\prime \prime}$ & 26.4, $\mathrm{CH}_{3}$ & $1.15 \mathrm{~s}$ \\
\hline
\end{tabular}

${ }^{a}$ Measured under acidic conditions (addition of $1.8 \% \mathrm{HCl}$; $\mathrm{pH}=4$; $10 \mu \mathrm{L} \mathrm{H} \mathrm{H}_{2} \mathrm{O}$ ) and at $\mathrm{T}=288 \mathrm{~K} .{ }^{1} \mathrm{H}: 750 \mathrm{MHz} ;{ }^{13} \mathrm{C}: 189 \mathrm{MHz}$. ${ }^{b}$ Chemical shifts were extracted from HSQC and HMBC spectra. ${ }^{c}$ Duplicated NMR signals due to the presence of diastereomers. ${ }^{d}$ Overlapped signals.

similar HPLC-ECD spectrum compared to the solution ECD of 1 in $\mathrm{MeOH}$. Accordingly, the weak ECD spectra of each of the two separated peaks suggested that they both represent nonracemic mixtures of two enantiomers and that the enantiomeric excess of the second-eluting diastereomer dominated the chiroptical data of 1. Similarly, two major peaks of $\mathbf{2}$ were separated under the same HPLC conditions, from which the first-eluting one had the same HPLC-ECD spectrum as the solution ECD of $\mathbf{2}$ (Figures S26, S31). Efforts to separate the enantiomers of the diastereomers by using different chiral stationary phases or eluent combinations were unsuccessful.

In order to elucidate the absolute configuration of the main stereoisomer of $\mathbf{1}$ and $\mathbf{2}$ dominating the ECD spectrum of the stereoisomeric mixtures, the solution time-dependent density functional theory (TDDFT)-ECD approach was applied for the arbitrarily chosen $\left(9 R, 1^{\prime} S\right)$ and $\left(9 S, 1^{\prime} S\right)$ diastereomers of 1 as well as for the $\left(9 R, 1^{\prime} S, 2^{\prime} R\right),\left(9 R, 1^{\prime} S, 2^{\prime} S\right),\left(9 S, 1^{\prime} S, 2^{\prime} R\right)$, and $\left(9 S, 1^{\prime} S, 2^{\prime} S\right)$ stereoisomers of $2^{4}$ Preliminary Merck Molecular Force Field (MMFF) searches resulted in 163-339 conformers in a $21 \mathrm{~kJ} / \mathrm{mol}$ energy window, which were reoptimized at the $\mathrm{B} 3 \mathrm{LYP} / 6-31+\mathrm{G}(\mathrm{d}, \mathrm{p})$ and the CAMB3LYP/TZVP PCM levels. TDDFT-ECD calculations were performed at four different levels (B3LYP, BH\&HLYP, CAMB3LYP, and PBE0) using the TZVP basis set with or without a solvent model as applied in the preceding DFT reoptimization step for each set of conformers. The computed ECD spectra showed a ca. 5-10-fold increase in intensities compared to the experimental solution ECD spectra, suggesting the presence of 
nonracemic diastereomeric mixtures, in accordance with the NMR and chiral HPLC analysis (Tables 1 and 2, Figures S25 and S26). ${ }^{5}$ Comparison of the experimental ECD spectra of the stereoisomeric mixtures with calculated ECD data of the selected stereoisomers showed that the major stereoisomer, dominating the experimental ECD of the samples, had a $\left(9 R, 1^{\prime} S\right.$ ) absolute configuration in $\mathbf{1}$ and $\mathbf{2}$ (Figures 2 and 3,

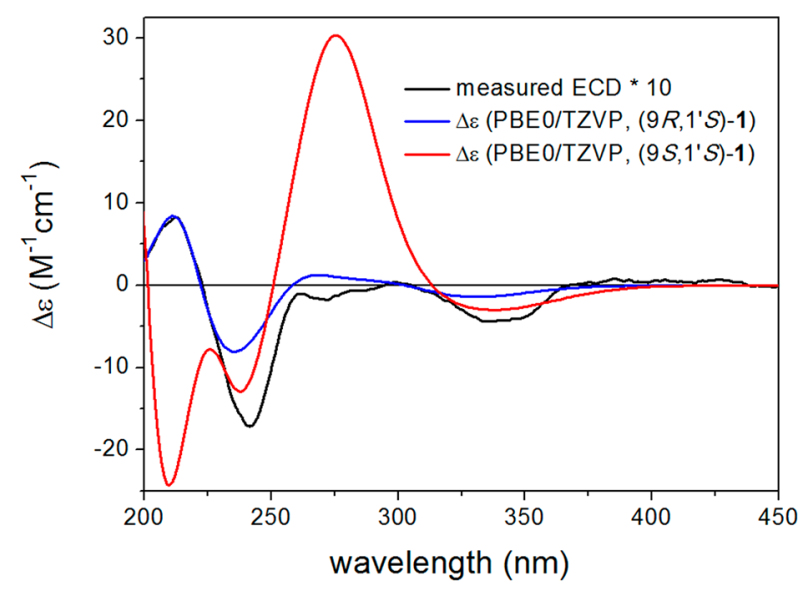

Figure 2. Experimental ECD spectrum of $\mathbf{1}$ in $\mathrm{MeOH}$ compared with the Boltzmann-weighted PBE0/TZVP PCM ECD spectra (average of 26 and 25 conformers, respectively) of $\left(9 R, 1^{\prime} S\right)-1$ and $\left(9 S, 1^{\prime} S\right)-1$ computed for the CAM-B3LYP/TZVP PCM.

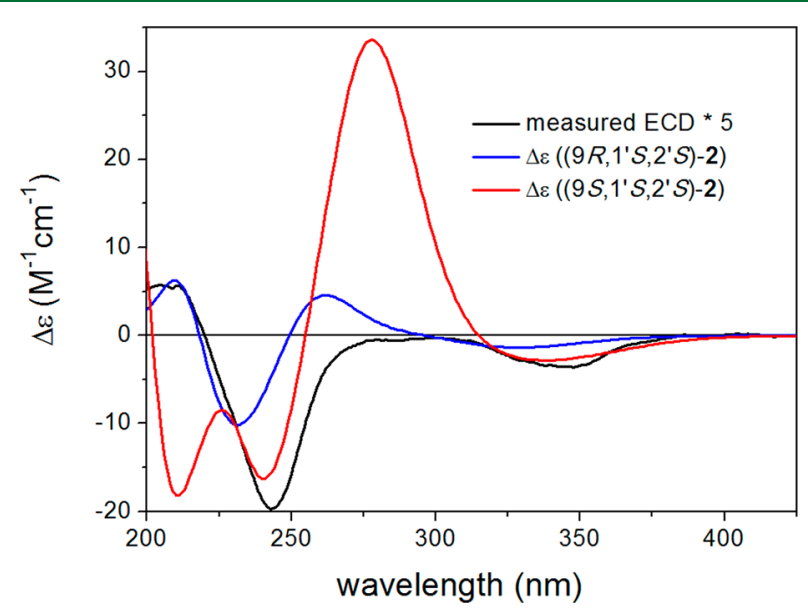

Figure 3. Experimental ECD spectrum of $\mathbf{2}$ in $\mathrm{MeOH}$ compared with the Boltzmann-weighted PBE0/TZVP PCM ECD spectra (average of 16 and 15 conformers, respectively) of ( $\left.9 R, 1^{\prime} S, 2^{\prime} S\right)-2$ and (9S,1'S,2'S)-2 computed for the CAM-B3LYP/TZVP PCM conformers.

respectively). The additional C-2' chirality center of 2 has a minor contribution to the ECD spectra, and its absolute configuration could not be determined (Figure S31). Furthermore, the ECD spectra computed for the distinct low-energy conformers as well as for those obtained at various levels of theory were rather similar, reducing the possibility of substantially different overall ECD spectra based on a Boltzmann population error. ${ }^{5,6}$ This observation can be attributed to the similarity of the low-energy conformers differing only in the orientation of the side chains (Figures S28 and S30). NMR calculations were also performed for all of the above-mentioned stereoisomers; ${ }^{7}$ comparison of the computed and experimental chemical shift values did not allow assignment of the diastereomers, probably due to the coordination effect of the DMSO solvent. ${ }^{8,9}$

The substitution pattern of the benzene of chaetolines A (1) and B (2) from this study resembles the core structure of recently reported chaetophenol derivatives isolated from $C$. indicum. ${ }^{2 \mathrm{~b}}$ One of the precursors of chaetophenols was proven to be the benzaldehyde derivative $\mathbf{A}$ (Scheme 1). A possible biosynthetic pathway for $\mathbf{1}$ and $\mathbf{2}$ originating from $\mathbf{A}$ is proposed in Scheme 1. Accordingly, the isoquinoline core in $\mathbf{1}$ and $\mathbf{2}$ is likely to be derived by initial Schiff-base formation between the amino group of leucine or isoleucine with one of the carbonyl groups of $\mathbf{A} .^{10}$ Subsequent ring closure and dehydration reactions would produce a delocalized isoquinolinium intermediate. ${ }^{11,12}$ The positive charge of the nitrogen atom could favor a delocalized ylide structure via basecatalyzed/enzymatic abstraction of the $\alpha$-proton of the amino acid residue, thus facilitating partial racemization at this position. Successive hydration and oxidation reactions would then result in the formation of the isoquinolinone intermediate $\mathbf{B}$ bearing both the L- and D-form of the respective amino acid. Prenyl transfer to $\mathbf{B}$ would lead to the phenoether $\mathbf{C}$. Oxidation of the $p$-cresol structure in $\mathbf{C}^{13}$ and subsequent intramolecular cyclization with the alkenyl ether would afford the pyran, and final hydration would yield compounds 1 and 2 .

The heterocyclic pyrano[3,2-f] isoquinoline core structure of $\mathbf{1}$ and $\mathbf{2}$ is unprecedented among natural products. As a partial substructure, this ring system is found exclusively in recently described highly fused naphthylisoquinoline alkaloids, cyclombandakamines $A_{1}$ and $A_{2}$, derived from the plant Ancistrocladus sp. ${ }^{14}$ In addition, the presence of a hydroxyisopropyl moiety at the 3-position of the pyran ring (C-9 in $\mathbf{1}$ and 2) has rarely been reported from fungi, with arugosins $C$ and $\mathrm{D}$ and chromanol derivatives being hitherto the only examples. $^{15}$

The biosynthetic NR-PKS genes corresponding to the biosynthesis of chaetophenols $\mathrm{A}-\mathrm{F}$ in $\mathrm{C}$. indicum remained silent under standard conditions but were activated in the presence of the HDAC inhibitor SBHA. ${ }^{2 b}$ Herein, production of chaetolines A (1) and B (2), which are assumed to be biosynthetically related to the aforementioned compounds, was stimulated by fermentation of Chaetomium sp. with autoclaved $P$. aeruginosa. Induction of fungal metabolism even in the absence of direct competition between studied microorganisms suggests the fungal response to be connected with exposure to conserved microbe-specific molecules, the socalled bacterial microbe-associated molecular patterns (MAMPs), ${ }^{16}$ which may be released after autoclaving $P$. aeruginosa. Intriguingly, a recent investigation on the immune response of the fungus Fusarium graminearum treated with MAMPs (flagellin, lipooligosaccharides, peptidoglycan) indicated significant transcriptional changes, among them the upregulation of genes involved in the biosynthesis of secondary metabolites (including polyketide synthase) and more remarkably in the metabolism of leucine and isoleucine. ${ }^{17}$ Thus, the induction of chaetolines A and B (1 and 2) may take place due to activation of the immune response of Chaetomium sp. by heat-resistant MAMPs from autoclaved P. aeruginosa.

Compounds 1 and $\mathbf{2}$ were inactive when evaluated against L5178Y mouse lymphoma cells (MIC > $20 \mu \mathrm{M}$ ) and against several human bacterial pathogens including $P$. aeruginosa, Acinetobacter baumannii, Escherichia coli, Klebsiella pneumoniae, and Staphylococcus aureus (MIC > $100 \mu \mathrm{M}$ ). The limited amount of isolated chaetolines A (1) and B (2) precluded 
Scheme 1. Postulated Biosynthetic Origin of Chaetolines A (1) and B (2)<smiles>C#CC#CCCCC(C)=O</smiles><smiles>[R]C(N)C(=O)O</smiles>

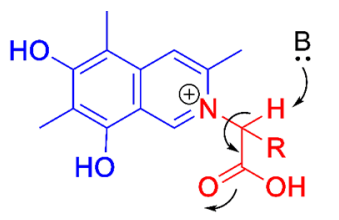<smiles>[R]C(C(O)O)=[N+]([O-])c1cc2c(C)c(O)c(C)c(O)c2cc1C</smiles>

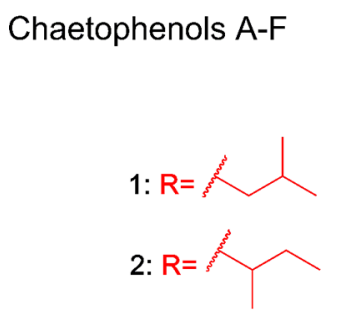<smiles>[R]C(C(=O)O)n1c(C)cc2c(C)c(OCC=C(C)C)c(C)c(O)c2c1=O</smiles><smiles>[R]C(C(=O)O)n1c(C)cc2c(C)c(O)c(C)c(O)c2c1=O</smiles><smiles>[R]C(C(=O)O)N1C(C)=Cc2c(C)c(O)c(C)c(O)c2C1O</smiles><smiles>C=[GeH2]</smiles><smiles>[R]C(C(=O)O)n1c(C)cc2c(CCC(C)=CC)c(OCC)c(C)c(O)c2c1=O</smiles><smiles>[R]C(C(=O)O)n1c(C)cc2c3c(c(C)c(O)c2c1=O)OC[C@H](C(C)C)C3</smiles><smiles>[R]C(C(=O)O)n1c(C)cc2c3c(c(C)c(O)c2c1=O)OCC(C(C)(C)O)C3</smiles>

1 and 2

further studies on the bioactivity profile of these metabolites. An increasing number of reports on secondary metabolites derived from cocultivation experiments without antimicrobial/ cytotoxic properties ${ }^{18-20}$ provide evidence that microbial crosstalk is more complex than straightforward expression of chemical defense due to competition for nutrients and/or space. The biological role of these intriguing metabolites remains to be investigated in future studies.

\section{EXPERIMENTAL SECTION}

General Experimental Procedures. Optical rotations were determined on a PerkinElmer-241 MC polarimeter. ${ }^{1} \mathrm{H},{ }^{13} \mathrm{C}$, and 2D NMR spectra were recorded on Bruker Avance III 600 or AV III HD 750 NMR spectrometers. The residual solvent signals were used for referencing spectra in ${ }^{1} \mathrm{H}$ and ${ }^{13} \mathrm{C}$ dimensions. Low-resolution mass spectra (ESI) were recorded on a Finnigan LCQ Deca mass spectrometer, and HRMS (ESI) spectra were obtained with an FTHRMS-Orbitrap (Thermo-Finnigan) mass spectrometer. ECD spectra were recorded on a J-810 spectropolarimeter. Solvents were distilled prior to use, and spectral grade solvents were applied for spectroscopic measurements. HPLC analysis was performed on a Dionex UltiMate3400 SD with an LPG-3400SD pump coupled to a photodiode array detector (DAD3000RS); routine detection was at 235, 254, 280, and $340 \mathrm{~nm}$. The separation column $(125 \mathrm{~mm} \times 4$ $\mathrm{mm}$ ) was prefilled with Eurosphere-10 $\mathrm{C}_{18}$ (Knauer, Germany), and the following gradient was used $\left(\mathrm{MeOH}, 0.1 \% \mathrm{HCOOH}\right.$ in $\left.\mathrm{H}_{2} \mathrm{O}\right): 0$ $\min (10 \% \mathrm{MeOH}), 5 \min (10 \% \mathrm{MeOH}), 35 \min (100 \% \mathrm{MeOH}), 45$ $\min (100 \% \mathrm{MeOH})$. Semipreparative HPLC was performed using a Merck Hitachi HPLC System (UV detector L-7400; pump L-7100; Eurosphere-100 $\mathrm{C}_{18}, 300 \mathrm{~mm} \times 8 \mathrm{~mm}$, Knauer, Germany). Employed stationary phases for column chromatography included Sephadex LH20 and Merck MN silica gel $60 \mathrm{M}(0.04-0.063 \mathrm{~mm})$. TLC plates with silica gel F254 (Merck, Darmstadt, Germany) were used to monitor fractions $\left(\mathrm{CH}_{2} \mathrm{Cl}_{2}-\mathrm{MeOH}\right.$ mixtures as mobile phase); detection was under UV at 254 and $366 \mathrm{~nm}$ or by spraying the plates with anisaldehyde reagent. Bacterial growth was monitored by measuring $\mathrm{OD}_{600}$ in a Tecan microtiter plate reader (Infinite M200, Tecan).

Biological Material and Cultivation of Microbes. The isolation and identification of the fungal endophyte Chaetomium sp. (strain CFSE1981), derived from leaves of the Cameroonian plant $S$. ellipticum (Euphorbiaceae), were carried out as described in our previous report (accession number in the GenBank database KU051539). ${ }^{3 a}$ The standard laboratory strain of $P$. aeruginosa ATCC 27853 was used in this study for the mixed fermentation experiment. The investigated microorganisms were subjected to solidphase cultivation on rice medium in Erlenmeyer flasks ( $1 \mathrm{~L}$ each). As a preincubation step, $P$. aeruginosa was grown in Müller Hinton broth overnight (at $30{ }^{\circ} \mathrm{C}$ with shaking at $80 \mathrm{rpm}$ ), and $10 \mathrm{~mL}$ of this broth was added to 10 flasks with rice medium ( $50.0 \mathrm{~g}$ per flask), which were further incubated for 4 days at $37{ }^{\circ} \mathrm{C}$. Afterward, these flasks were autoclaved at $121^{\circ} \mathrm{C}$ for $20 \mathrm{~min}$, and five of them were used as axenic bacterial control, whereas the remaining five were inoculated with Chaetomium sp. culture. Simultaneously, five further flasks containing rice medium were inoculated with Chaetomium sp. (axenic fungal control). Fungal and autoclaved bacterial monocultures were than incubated under static conditions for 21 days at $23{ }^{\circ} \mathrm{C}$, and Chaetomium sp. with autoclaved $P$. aeruginosa were kept until the stationary phase of growth was reached (35 days at $23{ }^{\circ} \mathrm{C}$ ). Subsequently, the cultures were extracted with $300 \mathrm{~mL}$ of EtOAc (140 rpm for $9 \mathrm{~h}$ ), and the combined filtrated extracts were washed with demineralized water and evaporated under vacuum until dryness. The extracts of monocultures and of Chaetomium sp. with autoclaved $P$. aeruginosa were then submitted to chemical profiling using HPLCDAD and LC-MS analyses.

Extraction and Isolation. The combined crude extract of cultures of Chaetomium sp. with autoclaved P. aeruginosa (2.6 g) was subjected to liquid-liquid partitioning against hexane, EtOAc, and water. The EtOAc fraction $(2.0 \mathrm{~g})$ was further purified by vacuum liquid chromatography (VLC) on silica gel using a step gradient of $n$ hexane-EtOAc followed by $\mathrm{CH}_{2} \mathrm{Cl}_{2}-\mathrm{MeOH}$ to give 13 fractions. Fraction 100EA (EtOAc 100\%; $250 \mathrm{mg}$ ) contained compounds 1 and 
2. Further separation of fraction 100EA using column chromatography on Sephadex-LH-20 with $\mathrm{MeOH}$ as an eluent followed by semipreparative HPLC employing a solvent gradient of $\mathrm{MeOH}-\mathrm{H}_{2} \mathrm{O}$ $(0.1 \% \mathrm{HCOOH})$ yielded compounds $1(2.0 \mathrm{mg})$ and $2(0.9 \mathrm{mg})$.

Chaetoline A (1): amorphous, yellowish powder; $[\alpha]_{\mathrm{D}}^{20}-38.7(c$ $0.10 \mathrm{MeOH}) ; \mathrm{UV}(\mathrm{MeOH}) \lambda_{\max } 348,252 \mathrm{~nm}$; ECD $\{\mathrm{MeOH}, \lambda[\mathrm{nm}]$ $\left.(\Delta \varepsilon), c=3.59 \times 10^{-4} \mathrm{M}\right\} 336(-0.44), 299(+0.04), 287 \mathrm{sh}(-0.06)$, 272sh (-0.18), $242(-1.72), 213(+0.82) \mathrm{nm} ;{ }^{1} \mathrm{H}$ and ${ }^{13} \mathrm{C}$ NMR see Table 1; HRESIMS $[\mathrm{M}+\mathrm{H}]^{+} m / z 418.2225$ (calcd for $\mathrm{C}_{23} \mathrm{H}_{32} \mathrm{NO}_{6}$, 418.2224).

Chaetoline $B$ (2): amorphous, yellowish powder; $[\alpha]_{\mathrm{D}}^{20}-43.8(c$ $0.10 \mathrm{MeOH}) ; \mathrm{UV}(\mathrm{MeOH}) \lambda_{\max } 349,251 \mathrm{~nm} ; \mathrm{ECD}\{\mathrm{MeOH}, \lambda[\mathrm{nm}]$ $\left.(\Delta \varepsilon), c=2.40 \times 10^{-4} \mathrm{M}\right\}=348(-0.72), 285 \mathrm{sh}(-0.11), 243$ (-3.94), 211sh $(+1.13) \mathrm{nm} ;{ }^{1} \mathrm{H}$ and ${ }^{13} \mathrm{C}$ NMR see Table 2; HRESIMS $[\mathrm{M}+\mathrm{H}]^{+} \mathrm{m} / z 418.2223$ (calcd for $\mathrm{C}_{23} \mathrm{H}_{32} \mathrm{NO}_{6}$, 418.2224)

Antibacterial Assay. Antibacterial screening of the compounds was carried out according to CLSI guidelines. ${ }^{21}$ Mueller-Hinton broth $(0.20 \%, \mathrm{w} / \mathrm{v}$, beef extract; $1.75 \%, \mathrm{w} / \mathrm{v}$, acid digest of casein; $0.15 \%, \mathrm{w} /$ $\mathrm{v}$, starch) was used to propagate the strains of $P$. aeruginosa (ATCC 27853), A. baumanii (ATCC BAA1605 and BAA747), E. coli (ATCC 25922), K. pneumoniae (ATCC 13883), and S. aureus (ATCC 29213 and 700699). After incubation at $37{ }^{\circ} \mathrm{C}$ for $24 \mathrm{~h}$, the 96 -well plates were checked by visual inspection. Moxifloxacin and rifampicin were used as the positive control for the Gram-positive and Gram-negative strains, respectively. Compounds were added from stock solution (10 $\mathrm{mg} / \mathrm{mL}$ in DMSO), resulting in a final DMSO amount of $0.64 \%$ at the highest antibiotic concentration tested $(64 \mu \mathrm{g} / \mathrm{mL})$. Serial 2-fold dilutions of antibiotics were prepared with DMSO being diluted along with the compounds.

Cell Viability Assay. Cytotoxicity was tested against L5178Y mouse lymphoma cells using an MTT assay and compared to that of untreated controls, as described previously. ${ }^{22}$ Experiments were repeated three times and carried out in triplicate. As negative controls, media with $0.1 \%$ ethylene glycol monomethyl ether/DMSO were included in the experiments. The depsipeptide kahalalide F, isolated from Elysia grandifolia, was used as a positive control.

Computational Section. Mixed torsional/low-mode conformational searches were carried out by using the Macromodel 10.8.011 ${ }^{23}$ software with the MMFF with an implicit solvent model for $\mathrm{CHCl}_{3}$ applying a $21 \mathrm{~kJ} / \mathrm{mol}$ energy window. Geometry optimizations $\left[\mathrm{B} 3 \mathrm{LYP} / 6-31+\mathrm{G}(\mathrm{d}, \mathrm{p})\right.$ in vacuo and CAM-B3LYP/TZVP ${ }^{24,25}$ with the PCM solvent model for MeCN], NMR [mPW1PW91/6$311+\mathrm{G}(2 \mathrm{~d}, \mathrm{p})^{7,26}$ in vacuo], and TDDFT [B3LYP/TZVP, BH\&HLYP/TZVP, CAM-B3LYP/TZVP, and PBE0/TZVP with the same or no solvent model as in the preceding optimization step] calculations were performed with Gaussian 09. ${ }^{27}$ The ECD spectra were generated as the sum of the Gaussians with $3000-3600 \mathrm{~cm}^{-1}$ half-height width (corresponding to ca. $15-17$ at $220 \mathrm{~nm}$ ) using dipole-velocity-computed rotational strengths. ${ }^{28}$ Boltzmann distributions were estimated from the B3LYP and the CAM-B3LYP energies. The MOLEKEL software package was used for visualization of the results. $^{29}$

\section{ASSOCIATED CONTENT}

\section{S Supporting Information}

The Supporting Information is available free of charge on the ACS Publications website at DOI: 10.1021/acs.jnatprod.8b00373.

General experimental procedures, analytical data, and copies of the ${ }^{1} \mathrm{H},{ }^{13} \mathrm{C}$, COSY, TOCSY, HSQC, HMBC, and ROESY NMR spectra and HPLC-ECD data of 1 and 2 (PDF)

\section{AUTHOR INFORMATION}

\section{Corresponding Authors}

*E-mail: elena.ancheeva@uni-duesseldorf.de.
*E-mail: georgios.daletos@uni-duesseldorf.de.

*E-mail: proksch@uni-duesseldorf.de.

ORCID

Elena Ancheeva: 0000-0002-2440-4427

Attila Mándi: 0000-0002-7867-7084

Georgios Daletos: 0000-0002-1636-6424

\section{Present Address}

Georgios Daletos, Department of Metabolic Biology, John Innes Centre, Norwich NR4 7UH, United Kingdom.

\section{Notes}

The authors declare no competing financial interest.

\section{ACKNOWLEDGMENTS}

This study was supported by grants of the DFG (GRK 2158) and the Manchot Foundation awarded to P.P. The research of T.K., A.M., and S.B.K. was supported by the EU and cofinanced by the European Regional Development Fund under the project GINOP-2.3.2-15-2016-00008. We thank the Governmental Information-Technology Development Agency (KIFÜ) for CPU time. The authors are grateful to Profs. W. E. G. Müller (Johannes Gutenberg University Mainz) and R. Kalscheuer (Heinrich Heine University Düsseldorf) for performing cytotoxicity and antibacterial screenings, respectively. The authors acknowledge access to the JülichDüsseldorf Biomolecular NMR Center.

\section{REFERENCES}

(1) (a) Brakhage, A. A.; Schroeckh, V. Fungal Genet. Biol. 2011, 48, 15-22. (b) Rutledge, P. J.; Challis, G. L. Nat. Rev. Microbiol. 2015, 13, 509-523.

(2) (a) Asai, T.; Morita, S.; Shirata, N.; Taniguchi, T.; Monde, K.; Sakurai, H.; Ozeki, T.; Oshima, Y. Org. Lett. 2012, 14, 5456-5459. (b) Asai, T.; Yamamoto, T.; Shirata, N.; Taniguchi, T.; Monde, K.; Fujii, I.; Gomi, K.; Oshima, Y. Org. Lett. 2013, 15, 3346-3349. (c) Asai, T.; Taniguchi, T.; Yamamoto, T.; Monde, K.; Oshima, Y. Org. Lett. 2013, 15, 4320-4323. (d) Asai, T.; Tsukada, K.; Ise, S.; Shirata, N.; Hashimoto, M.; Fujii, I.; Gomi, K.; Nakagawara, K.; Kodama, E. N.; Oshima, Y. Nat. Chem. 2015, 7, 737-743.

(3) (a) Akone, S. H.; Mándi, A.; Kurtán, T.; Hartmann, R.; Lin, W.; Daletos, G.; Proksch, P. Tetrahedron 2016, 72, 6340-6347. (b) Ancheeva, E.; Küppers, L.; Akone, S. H.; Ebrahim, W.; Liu, Z.; Mándi, A.; Kurtán, T.; Lin, W.; Orfali, R.; Rehberg, N.; Kalscheuer, R.; Daletos, G.; Proksch, P. Eur. J. Org. Chem. 2017, 2017, 32563264.

(4) (a) Pescitelli, G.; Bruhn, T. Chirality 2016, 28, 466-474. (b) Li, H.-L.; Li, X.-M.; Mándi, A.; Antus, S.; Li, X.; Zhang, P.; Liu, Y.; Kurtán, T.; Wang, B.-G. J. Org. Chem. 2017, 82, 9946-9954.

(5) Mándi, A.; Swamy, M. M. M.; Taniguchi, T.; Anetai, M.; Monde, K. Chirality 2016, 28, 453-459.

(6) Sun, P.; Xu, D.-X.; Mándi, A.; Kurtán, T.; Li, T.-J.; Schulz, B.; Zhang, W. J. Org. Chem. 2013, 78, 7030-7047.

(7) Lodewyk, M. W.; Siebert, M. R.; Tantillo, D. J. Chem. Rev. 2012, $112,1839-1862$.

(8) (a) Nicu, V. P.; Baerends, E. J.; Polavarapu, P. L. J. Phys. Chem. A 2012, 116, 8366-8373. (b) Bereczki, I.; Mándi, A.; Rőth, E.; Borbás, A.; Fizil, Á.; Komáromi, I.; Sipos, A.; Kurtán, T.; Batta, G.; Ostorházi, E.; Rozgonyi, F.; Vanderlinden, E.; Naesens, L.; Sztaricskai, F.; Herczegh, P. Eur. J. Med. Chem. 2015, 94, 73-86.

(9) The presence of both L- and D-amino acid residues in the structures of fungal secondary metabolites has been previously described. A notable example is gymnastatin $\mathrm{N}$, which was isolated from the fungus Arachniotus punctatus as a mixture of two diastereomers $(52: 48)$ differing in the absolute configuration of the stereocenter residing at the tyrosine moiety: Phoon, C. W.; 
Somanadhan, B.; Heng, S. C. H.; Ngo, A.; Ng, S. B.; Butler, M. S.;

Buss, A. D.; Sim, M. M. Tetrahedron 2004, 60, 11619-11628.

(10) Chaetoindicins $\mathrm{A}-\mathrm{C}$, isoquinoline alkaloids from Chaetomium indicum, may also biosynthetically arise from similar polyketide precursors due to the characteristic substitution pattern of isoquinoline substructure. Li, G.-Y.; Li, B.-G.; Yang, T.; Liu, G.-Y.; Zhang, G.L. Org. Lett. 2006, 8, 3613-3615.

(11) Katritzky, A. R.; Grzeskowiak, N. E.; Eweiss, N. F.; Elsherbini,

E. A. J. Chem. Soc., Perkin Trans. 1 1983, 497-500.

(12) Pilgrim, B. S.; Gatland, A. E.; Esteves, C. H. A.; McTernan, C. T.; Jones, G. R.; Tatton, M. R.; Procopiou, P. A.; Donohoe, T. J. Org. Biomol. Chem. 2016, 14, 1065-1090.

(13) Aguer, J.-P.; Mailhot, G.; Bolte, M. New J. Chem. 2006, 30, 191-196.

(14) Lombe, B. K.; Bruhn, T.; Feineis, D.; Mudogo, V.; Brun, R.; Bringmann, G. Org. Lett. 2017, 19, 1342-1345.

(15) (a) Ballantine, J. A.; Ferrito, V.; Hassall, C. H.; Jenkins, M. L. J. Chem. Soc., Perkin Trans. 1 1973, 1825-1830. (b) Chexal, K. K.; Holker, J. S. E.; Simpson, T. J. J. Chem. Soc., Perkin Trans. 1 1975, 549-554. (c) Achenbach, H.; Mühlenfeld, A.; Brillinger, G. U. Liebigs Ann. Chem. 1985, 1985, 1596-1628.

(16) Recent findings provided evidence that fungi possess genes encoding cytosolic nucleotide oligomerization domain-like receptor (NLR) proteins closely related to those of plants and animals, which mediate non-self-recognition, taking part in innate immunity. Uehling, J.; Deveau, A.; Paoletti, M. PLoS Pathog. 2017, 13, e1006578.

(17) Ipcho, S.; Sundelin, T.; Erbs, G.; Kistler, H. C.; Newman, M.A.; Olsson, S. G3: (Bethesda) 2016, 6, 1585-1595.

(18) Shang, Z.; Salim, A. A.; Capon, R. J. J. Nat. Prod. 2017, 80, 1167-1172.

(19) Hoshino, S.; Okada, M.; Wakimoto, T.; Zhang, H.; Hayashi, F.; Onaka, H.; Abe, I. J. Nat. Prod. 2015, 78, 3011-3017.

(20) Hoshino, S.; Okada, M.; Awakawa, T.; Asamizu, S.; Onaka, H.; Abe, I. Org. Lett. 2017, 19, 4992-4995.

(21) CLSI, Methods for Dilution Antimicrobial Susceptibility Tests for Bacteria That Grow Aerobically, CLSI Document M07-A10, Approved Standard (10th ed.); Clinical and Laboratory Standards Institute: Wayne, PA, 2015.

(22) Ashour, M.; Edrada, R.; Ebel, R.; Wray, V.; Watjen, W.; Padmakumar, K.; Müller, W. E. G.; Lin, W. H.; Proksch, P. J. Nat. Prod. 2006, 69, 1547-1553.

(23) MacroModel; Schrödinger, LLC, 2015, http://www. schrodinger.com/MacroModel.

(24) Yanai, T.; Tew, D. P.; Handy, N. C. Chem. Phys. Lett. 2004, $393,51-57$.

(25) Pescitelli, G.; Di Bari, L.; Berova, N. Chem. Soc. Rev. 2011, 40, $4603-4625$.

(26) Elnaggar, M. S.; Ebrahim, W.; Mándi, A.; Kurtán, T.; Müller, W. E. G.; Kalscheuer, R.; Singab, A.; Lin, W.; Liu, Z.; Proksch, P. RSC Adv. 2017, 7, 30640-30649.

(27) Frisch, M. J.; Trucks, G. W.; Schlegel, H. B.; Scuseria, G. E.; Robb, M. A.; Cheeseman, J. R.; Scalmani, G.; Barone, V.; Mennucci, B.; Petersson, G. A.; Nakatsuji, H.; Caricato, M.; Li, X.; Hratchian, H. P.; Izmaylov, A. F.; Bloino, J.; Zheng, G.; Sonnenberg, J. L.; Hada, M.; Ehara, M.; Toyota, K.; Fukuda, R.; Hasegawa, J.; Ishida, M.; Nakajima, T.; Honda, Y.; Kitao, O.; Nakai, H.; Vreven, T.; Montgomery, J. A., Jr; Peralta, J. E.; Ogliaro, F.; Bearpark, M.; Heyd, J. J.; Brothers, E.; Kudin, K. N.; Staroverov, V. N.; Kobayashi, R.; Normand, J.; Raghavachari, K.; Rendell, A.; Burant, J. C.; Iyengar, S. S.; Tomasi, J.; Cossi, M.; Rega, N.; Millam, J. M.; Klene, M.; Knox, J. E.; Cross, J. B.; Bakken, V.; Adamo, C.; Jaramillo, J.; Gomperts, R.; Stratmann, R. E.; Yazyev, O.; Austin, A. J.; Cammi, R.; Pomelli, C.; Ochterski, J. W.; Martin, R. L.; Morokuma, K.; Zakrzewski, V. G.; Voth, G. A.; Salvador, P.; Dannenberg, J. J.; Dapprich, S.; Daniels, A. D.; Farkas, Ö.; Foresman, J. B.; Ortiz, J. V.; Cioslowski, J.; Fox, D. J. Gaussian 09, Revision B.01; Gaussian, Inc.: Wallingford, CT, 2010.

(28) Stephens, P. J.; Harada, N. Chirality 2010, 22, 229-233.

(29) Varetto, U., MOLEKEL, v. 5.4; Swiss National Supercomputing Centre: Manno, Switzerland, 2009. 